\title{
The effect of different factors on investment decision of enterprises in industrial parts
}

\author{
Quynh Nam Vua , Thi Hoai Huong Hoang ${ }^{b}$ and Thi Yen Le ${ }^{c^{*}}$
}

\author{
${ }^{a}$ Thai Nguyen University of economics and business administration, Vietnam \\ ${ }^{b}$ Quy Nhon university, Vietnam \\ ${ }^{c}$ Hanoi Architectural University, Vietnam

\section{CHRON I C L E A B S T RACT}

\section{Article history:}

Received December 22019

Received in revised format March

202020

Accepted March 242020

Available online

March 242020

Keywords:

Industrial parks

Vietnam

Attracting investment

Vietnam

\begin{abstract}
Attracting investment capital of enterprises into industrial parks has become an important task for countries when building and developing industrial parks to meet the economic goals of the country. To attract enterprises' investment capital into industrial parks, it is important to study what the enterprises need and whether or not they have met the needs of the enterprises. This examination was designed to analyze the factors affecting the investment decisions of enterprises in industrial parks in Vietnam whereby serving as the basis for proposing recommendations to improve the efficiency of attracting investment capital of enterprises in industrial parks in Vietnam. Research findings indicate that some factors influencing enterprises' investment decisions in industrial parks include: Local institutions, human resources, local advantages and infrastructure. Based on that analysis, the study proposes several recommendations to attract investment in industrial parks in Vietnam.
\end{abstract}

\section{Introduction}

After more than thirty years of renovation in Vietnam, the socio-economic situation has changed significantly. The economic growth rate is quite fast, the process of industrialization and modernization of the country has been accelerated. Learning from the experience of the leading developed industrial countries, Vietnam has built an "industrial park" model to attract investment capital to fulfil the country's socio-economic goals. The industrial park was built to concentrate the most favorable conditions for domestic and foreign investors, thereby contributing to increase the attractiveness and competitiveness of the investment environment. According to the Ministry of Planning and Investment's statistics on industrial park operation reports, as of June 2019, Vietnam has maintained 326 industrial parks built with a total natural land area of about 95.5 thousand hectares, and 251 industrial parks have been put into operation with a total natural land area of about 66.2 thousand hectares and 75 industrial parks are in the step of compensation and site clearance and construction with a total area of about 29.3 thousand hectares. The occupancy rate of operating industrial parks is nearly $74 \%$. The total number of foreign-invested projects investing in industrial parks reached about 8900 projects with a total registered capital of about 186 billion USD. For domestic investment projects, industrial parks have attracted about 9086 projects with a total registered capital of about VND 2060.5 trillion. Currently, the industrial parks have created jobs for about 3.6 million workers. The operation of industrial parks has shown its position and role in Vietnam's economic development. However, besides those achievements, the issue of attracting investment capital into industrial parks in Vietnam is still a modest number compared to the available potential, specifically. The industrial parks which are under

* Corresponding author.

E-mail address: lethiyenktdt@gmail.com (T. Y. Le) 
development but not yet in operation are relatively large; besides, industrial parks have been operating with new investment enterprises relatively low. Facing that situation, it is necessary to study the factors influencing enterprises' investment decisions in industrial parks. The findings are the basis for proposing recommendations to contribute for improving the efficiency of attracting investment capital into industrial parks and it is the basis for proposing policies for managers.

\section{Literature review}

Attracting investment in industrial parks has received the attention of not only researchers but also policymakers. From the perspective of Lin and Tzeng (2009) this is important when studying the factors influencing the investor's choice of investment location in industrial parks. The study also compares different industrial parks. With four groups of aspects analyzed in the study: Human resources, technological resources, investment in the environment and market development with 28 evaluation criteria to determine the properties of clusters. Shatz and Venables (2000) analyzed the motivations of multinational corporations when choosing overseas investment locations for two main reasons: The first is to exploit the domestic market of the host country (also known as cross-linked FDI) and the second is to minimize the cost of its production inputs (also called verticallinked FDI). Originating from these two engines, the majority of FDI inflows into developed countries are to exploit the local market, while FDI inflows into developing economies are to reduce production input costs. The characteristics of cross-linked FDI are to seek conditions to access the market of the host country with more open investment. Instead of exporting goods directly to that market, companies will weigh between fixed costs to build production facilities in foreign locations with variable costs reduced from freight charges or tariffs apply. Besides, companies investing directly in a country must also consider the costs incurred when operating in the host country, for example, costs related to administrative procedures, applicable taxes and policy adjustments.

\section{Table 1}

Summary of influencing factors to attract investment capital into industrial parks

\begin{tabular}{|c|c|c|c|}
\hline No. & Factor group & Describe & The authors studied \\
\hline 1 & $\begin{array}{l}\text { Characteristics of the } \\
\text { enterprise }\end{array}$ & $\begin{array}{l}\text { Characteristics of the enterprise such as operating time, size of } \\
\text { the enterprise, etc. }\end{array}$ & Nelson (2005), Nguyen Dinh Tho (2009) \\
\hline 2 & $\begin{array}{l}\text { Characteristics of } \\
\text { manager }\end{array}$ & $\begin{array}{l}\text { These are factors related to the highest administrators in the } \\
\text { enterprise. }\end{array}$ & Yeung et al. (2009), Kotler et al. (2002) \\
\hline 3 & Infrastructure & $\begin{array}{l}\text { Group of factors on infrastructure such as communication, } \\
\text { transport, and technological development, etc. }\end{array}$ & $\begin{array}{l}\text { Dunning (1997), Kotler et al. (2002), Gilmore et } \\
\text { al. (2003), Nguyen Dinh Tho (2008), Le Hoang } \\
\text { Ba Huyen (2015) }\end{array}$ \\
\hline 4 & Local advantages & $\begin{array}{l}\text { These are factors of local advantages such as product consumption } \\
\text { market, advantages of natural conditions such as (geographical } \\
\text { location, natural resources, material areas etc. }\end{array}$ & $\begin{array}{l}\text { Dunning John H (1997), Leung (2002), Gilmore } \\
\text { et al. (2003), Le Hoang Ba Huyen (2015). }\end{array}$ \\
\hline 5 & Local institutions & $\begin{array}{l}\text { These are specific economic policies and economic management } \\
\text { institutions, including clear incentives, preferential policies } \\
\text { (which are government or local support policies such as taxes, land } \\
\text { rents, support services etc. These are government or local support } \\
\text { policies such as taxes, land rents, and support services) }\end{array}$ & $\begin{array}{l}\text { Nguyen Dinh Tho (2009), Alam \&Stafford } \\
\text { (1985), Hodgkinson (1989), Dunning (1997), } \\
\text { Kotler et al. (2002), Gilmore et al. (2003), Le } \\
\text { Hoang Ba Huyen(2015) }\end{array}$ \\
\hline 6 & Human Resources & $\begin{array}{l}\text { That is the quantity and quality of labor to ensure qualified and } \\
\text { skills appropriate to the needs of investors. }\end{array}$ & $\begin{array}{l}\text { Dunning(1997), Kotler et al. (2002), Le Hoang } \\
\text { Ba Huyen (2015) }\end{array}$ \\
\hline
\end{tabular}

Source: Compiled by author

A country that creates a business investment environment with the best transaction costs will have a competitive advantage to attract global FDI. Therefore, the investment and development of industrial parks in developing countries will create outstanding advantages in terms of costs and policies to attract foreign investors. Research by Akifumi (2005) explained how the success of industrial zones affects the investment decision on industrial zones. The planning of concentrated industrial parks thereby attracts investors to build the infrastructure of industrial parks, applying preferential mechanisms to investors operating in industrial parks will create conditions for promoting production local industry and increase state management capacity for industrial park production activities. Besides, the industrial park development will promote transfer and innovation of research production technology. In the cost approach, it was pointed out that the main factors affecting the investor's investment position include transportation costs, labor costs, the closeness of auxiliary industrial facilities, and advantages in logistics and marketing. Research by Porter (1990), Porter (2000) on competitive advantage indicates that location of investment, industry/industry complexes and company strategies have taken a dynamic approach to investment decision engines, highlighting the role of industrial / industry complexes in the enterprise's competitive strategy, at the same time, analyzing the role of investment locations in the process of forming competitive advantages of enterprises. Studying the investment decision-making process, in the view of Robbins and Coulter (1996), the decision-making process consists of seven steps; including defining the problem, setting the criteria for the decision, quantifying standards, developing options, assessing and choosing the optimal plan, organizing the implementation of the plan and ultimately evaluating the effectiveness of the decision. 


\subsection{Data collection}

Determining the size of the sample during the study of socio-economic issues, it is very important to select a representative sample that is large enough. Factors that need to be considered to determine the correct sample size for a study include accuracy, quality of data, cost and time for data collection. To get a statistically consistent result and avoid unfortunate errors in the sampling process, the team determined the sample size in the way of Hair et al. (1980). Accordingly, to use the factor analysis method, the minimum sample size is 50 , preferably 100 and the observation rate/measurement variable is $5 / 1$, meaning a measurement variable needs a minimum of 5 observations. To serve this research, the authors carried a survey and collected survey results of 311 enterprises operating in Vietnam. The collected information ensures the sample size required for the study model.

*) Building survey questionnaire: The questionnaire is organized into two main parts as follows:

+ General information about the enterprises

+ Assessment of enterprises about factors affecting attract investment capital of enterprises into industrial parks.

The data after being surveyed will be imported into excel software, with 383 questionnaires issued, the author collected 311 surveys, if the questionnaire meets these information requirements, the authors will perform data entry and data analysis.

\subsection{Data analysis methods}

Research using exploratory factor analysis (EFA) and Binary Logistic regression to analyze the influence of factors on enterprises' investment attraction in industrial parks.

\section{Results}

Enterprises are the entities directly linked in the process of attracting investment capital into industrial parks. The opinions of enterprises will help build the solution closest to the desire enterprises and make industrial parks more attractive to investors. With the collected survey data, the research will conduct a factor analysis to explore the factors affecting business investment decisions in industrial parks, after that, the study will apply logistics regression to analyze the influence of factors on investment decisions of enterprises in industrial parks. To perform the exploratory factor analysis, the research team first tested the reliability of the scales using the Cronbach's alpha coefficient, the results show that Cronbach's coefficient alpha of common items is satisfactory, after that, the research team performed data testing for the study to be suitable for performing factor analysis or not using KMO and Bartlett's tests, the results showed that:

\section{Table 2}

KMO and Bartlett's Test

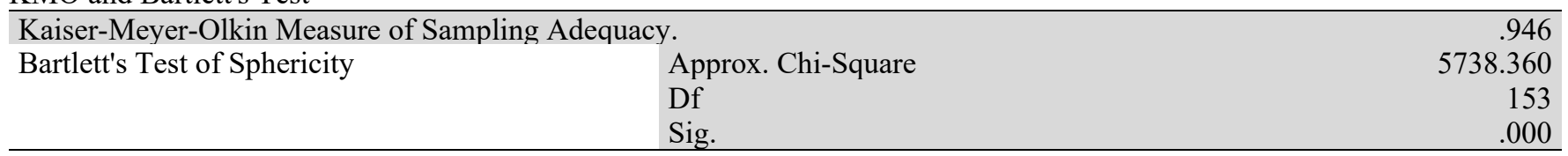

Source: Analytical results of the author

The results of KMO and Bartlett's Test in Table 2 show that this database is completely suitable because the test value reached 0.946 (in the range of 0.5 to 1 ) with statistical significance at $1 \%$ (Sig. $=0.000<0.005$ ). So, the author's research model is appropriate. For factor analysis, the study used specific values (Eigenvalue) to determine the number of factors given in Table 3. The analysis results show that corresponding to 18 observed variables, 18 calculated characteristic values, after the final EFA analysis, 4 factors with characteristic values equal to or greater than 1 were retained, the remaining factors have specific values (eigenvalue) less than 1 will not be used, which means 18 observed variables will converge to 4 factors.

In addition, from the research findings show that the "Rotation sums of squared loadings" reached a high level (81.417\%), which implies that the use of four factors representing 18 observed variables explained more than $80 \%$ of the observed variables. For the study in the field of social sciences, a total factor index of about $50 \%$ is calculated as acceptable, so conclusions can be made to use 4 factors to reflect the information of 18 observations. 
Table 3

Total Variance Explained

\begin{tabular}{|c|c|c|c|c|c|c|c|c|c|}
\hline \multirow[b]{2}{*}{ Component } & \multicolumn{3}{|c|}{ Initial Eigenvalues } & \multicolumn{3}{|c|}{$\begin{array}{l}\text { Extraction Sums of Squared } \\
\text { Loadings }\end{array}$} & \multicolumn{3}{|c|}{$\begin{array}{l}\text { Rotation Sums of Squared } \\
\text { Loadings }\end{array}$} \\
\hline & Total & $\begin{array}{c}\% \text { of } \\
\text { Variance }\end{array}$ & $\begin{array}{c}\text { Cumulative } \\
\%\end{array}$ & Total & $\begin{array}{c}\% \text { of } \\
\text { Variance }\end{array}$ & $\begin{array}{c}\text { Cumulative } \\
\%\end{array}$ & Total & $\begin{array}{c}\% \text { of } \\
\text { Variance }\end{array}$ & $\begin{array}{c}\text { Cumulative } \\
\%\end{array}$ \\
\hline 1 & 10.287 & 57.147 & 57.147 & 10.287 & 57.147 & 57.147 & 4.674 & 25.966 & 25.966 \\
\hline 2 & 2.039 & 11.328 & 68.475 & 2.039 & 11.328 & 68.475 & 3.643 & 20.238 & 46.204 \\
\hline 3 & 1.231 & 6.839 & 75.315 & 1.231 & 6.839 & 75.315 & 3.470 & 19.280 & 65.484 \\
\hline 4 & 1.050 & 5.833 & 81.147 & 1.050 & 5.833 & 81.147 & 2.819 & 15.664 & 81.147 \\
\hline 5 & .644 & 3.580 & 84.728 & & & & & & \\
\hline 6 & .476 & 2.644 & 87.372 & & & & & & \\
\hline 7 & .354 & 1.965 & 89.336 & & & & & & \\
\hline 8 & 293 & 1.630 & 90.967 & & & & & & \\
\hline 9 & .266 & 1.478 & 92.445 & & & & & & \\
\hline 10 & .227 & 1.263 & 93.708 & & & & & & \\
\hline 11 & .206 & 1.146 & 94.854 & & & & & & \\
\hline 12 & .190 & 1.056 & 95.910 & & & & & & \\
\hline 13 & .165 & .917 & 96.827 & & & & & & \\
\hline 14 & .139 & .772 & 97.600 & & & & & & \\
\hline 15 & .131 & .728 & 98.328 & & & & & & \\
\hline 16 & .120 & .669 & 98.997 & & & & & & \\
\hline 17 & .096 & .533 & 99.529 & & & & & & \\
\hline 18 & .085 & .471 & 100.000 & & & & & & \\
\hline
\end{tabular}

Source: Analytical results of the author

Table 4

Rotated Component Matrix

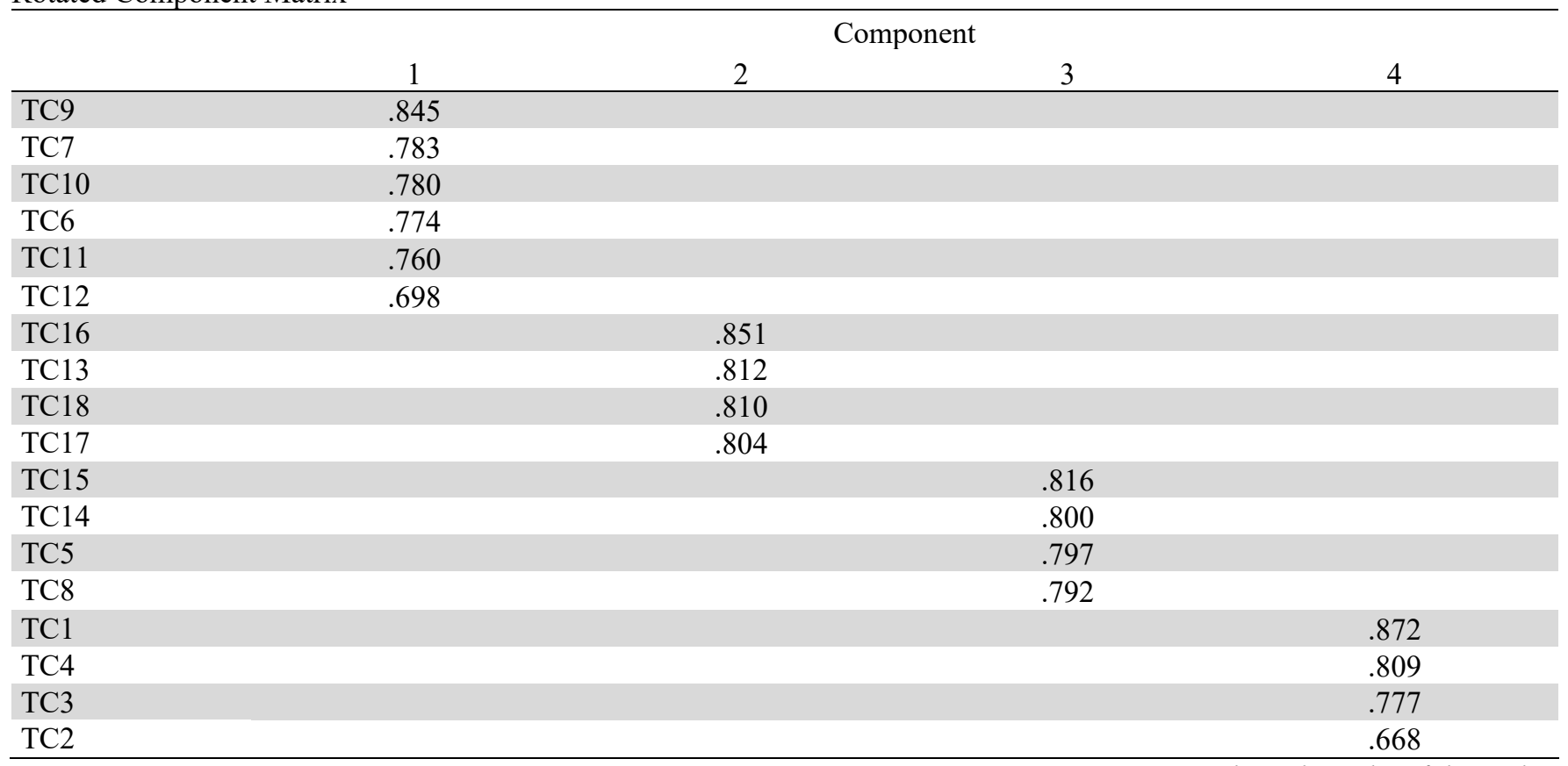

Source: Analytical results of the author

Based on the rotation matrix of these factors, the scales were extracted into 4 specific groups of factors as follows:

(1) The first group of factors includes 6 observed variables, and the authors named the group of factors: "Local institutions", It consists of 6 observed variables: TC6: Quick, simple administrative procedures; TC7: Quick customs clearance; TC9: Cost of renting land in industrial parks is cheaper than outside of IPs; TC10: Local leaders are willing to support investors; TC11: Documents and administrative procedures are quickly deployed to investors; TC12: Good investment incentive policies of local governments. 
The author set the criteria group 1 denoted by $\mathrm{FACl} 1$ with the equation:

$\mathrm{FAC} 1=0.774 \mathrm{TC} 6+0.783 \mathrm{TC} 7+0.845 \mathrm{TC} 9+0.78 \mathrm{TC} 10+0.76 \mathrm{TC} 11+0.698 \mathrm{TC} 12$

(2) The second group of factors includes 4 observed variables and the author named the group "Labor": The labor factor consists of 4 observed variables: TC13: Labor meets the requirements of quantity; TC16: Labor meets the requirements of quality; TC17: Labor can acquire and use technology well; TC18: Labor has discipline, meeting investor requirements.

The authors have set the criteria group 2 denoted by FAC2 with the equation:

$\mathrm{FAC} 2=0.812 \mathrm{TC} 13+0.851 \mathrm{TC} 16+0.804 \mathrm{TC} 17+0.81 \mathrm{TC} 18$

(3) The third group of factors includes four observed variables and the author named the group "Local advantages", where:

TC5: The location of the industrial park is convenient for investors; TC8: Investment and Trade Promotion Centre provides good support for investors; TC14: Good product consumption market; TC15: Advantages of supporting industries compared to other localities.

The authors set the criterion group 3 symbols denoted by FAC3 with the equation:

$\mathrm{FAC} 3=0.797 \mathrm{TC} 5+0.792 \mathrm{TC} 8+0.800 \mathrm{TC} 14+0.816 \mathrm{TC} 15$

(4) The fourth group of factors consists of four observed variables and the author named the group "The infrastructure".

The "infrastructure" group consists of four observed variables: TC1: Convenient transportation system inside and outside the industrial park; TC2: The electrical system in the industrial park is stable; TC3: Lighting system in the industrial park is stable and TC4: Technical infrastructure system for secured industrial parks (internet, post, telephone network)

The authors set the criteria group 4 denoted as FAC4 with equations:

$\mathrm{FAC} 4=0.872 \mathrm{TC} 1+0.668 \mathrm{TC} 2+0.777 \mathrm{TC} 3+0.809 \mathrm{TC} 4$

After performing exploratory factor analysis (EFA), the study uses Binary Logistic regression to analyze the influence of factors on the attraction of enterprises' investment capital into industrial parks. Which:

Dependent variable (Y): Investment decision of the enterprise in industrial zones; $\mathrm{Y}$ gets a value of 1 when deciding to invest and a value of 0 when not investing.

Independent variable:

+ Institutional factors are also studied in the very popular study in Vietnam by the Vietnam Chamber of Commerce and Industry (VCCI) it is a study of the provincial competitiveness index PCI. Special economic zones are allowed to apply specific economic policies and economic management institutions, not providing budgets but creating mechanisms, these include more open incentives than other countries for foreign investors, along with high autonomy coupled with doing well in operation management of special economic zone (Aggarwal, 2007).

+ Labour (FAC2): Human resources are considered as one of the important factors affecting FDI enterprises' attraction (Dunning, 1997). Investors will select the area, meeting the requirements of quantity, quality and price of labor. Labor quality is a competitive advantage for investors in high technology content areas, using modern technology (Gilmore et al., 2003). This factor was also confirmed to be an important influence in the research of Nguyen Dinh Tho (2009).

+ Local advantages (FAC3): In the study of factors affecting the decision to invest in Vietnamese industrial parks by Mai Van Nam and Nguyen Thanh $\mathrm{Vu}$ (2010), the authors mentioned 6 factors and the case study results are typical industrial zones of Tien Giang province that have identified three groups of factors affecting the investment decisions of enterprises; namely infrastructure, human resources and location of the industrial park where the location factor of the industrial park most strongly influences investment decisions. The geographical location of the economic zone is also mentioned as a key to the success of economic zones in the comprehensive study of UNIDO (2015). 
+ Infrastructure (FAC4): Infrastructure plays a very important influence on the production and business efficiency of enterprises. This is also a top concern of investors when making investment decisions (Le Hoang Ba Huyen, 2015; Mai Van Nam \&Nguyen Thanh $\mathrm{Vu}, 2010$ ). Good infrastructure is one of the important factors that help reduce the business costs of investors (Gilmore et al., 2003). Outdated infrastructure will increase incoming investment costs and create barriers to investment activities. The theory of Durning (1997), the theory of local marketing by Kotler et al. (2002) as well as the experiments of Nguyen Dinh Tho (2008) and Le Hoang Ba Huyen (2015) have proved the importance of this factor.

+) Factors that belong to within enterprises: The scales used are the Gender of enterprise leadership (GT), Qualifications of enterprise managers (HV); Management experience (KN); Firm size (QM) and uptime of the enterprise (TG), these are factors related to the personal opinion of the top managers in the investment. From the perspective of behavioral financiers, factors such as diagnosis, bias, effect framework, representation, sense of loss, risk aversion, etc... Influence and change investor decisions (Pavabutr P, 2002). However, studies carried by Waweru et al. (2008) show that investment decision making is also influenced by psychological, emotional and behavioral factors. Specifically, investment decisions are influenced by individual investor desires, goals, prejudices, and emotions. The study of Sandberg \& Hoper (1987) also complements this view.

To perform the regression, firstly, research is performed to test the suitability of the model:

Table 5

Omnibus Tests of Model Coefficients

\begin{tabular}{llccc}
\hline & & Chi-square & df & Sig. \\
\hline Step 1 & Step & 119.826 & 9 & .000 \\
& Block & 119.826 & 9 & .000 \\
& Model & 119.826 & 9 & .000 \\
\hline
\end{tabular}

According to the results of testing the suitability of the model, with $\operatorname{Sig}$ coefficient $<0.05$, the correlation between the dependent variable and the independent variables in the model is statistically significant with confidence intervals above $99 \%$.

Table 6

Model Summary

\begin{tabular}{lccc}
\hline Step & -2 Log likelihood & Cox \& Snell R Square & Adjusted-R Square \\
\hline 1 & $221.463^{\mathrm{a}}$ & .320 & .480 \\
\hline & & Source: Analysis results from the author's research data
\end{tabular}

The level of explanation of the model, with the $\mathrm{R}^{2}$ coefficient $=0.48$, indicates that about $48 \%$ of the variation of the dependent variable is explained by the independent variables in the model, the rest is due to other factors.

\section{Table 7}

Classification Table

\begin{tabular}{|c|c|c|c|c|c|}
\hline & & & & Predicted & \\
\hline & & & & $\mathrm{Y}$ & \\
\hline & & & .0000000000000000 & 1.0000000000000000 & Percentage Correct \\
\hline Step 1 & $\mathrm{Y}$ & .0000000000000000 & 224 & 13 & 94.5 \\
\hline & & 1.0000000000000000 & 29 & 45 & 60.8 \\
\hline & & entage & & & 86.5 \\
\hline
\end{tabular}

Source: Analysis results from the author's research data

The results of the forecast accuracy table show that in a total of 237 cases forecasted without investment, the accurate forecast model was 224 cases, with an accurate prediction rate of $94.5 \%$. As for 74 cases with investment decisions, which the model accurately predicts 45 cases, the correct prediction rate is about $60.8 \%$. From that, calculating the correct prediction rate of the model is $86.5 \%$.

Research findings show that:

+ Local institutions (FAC1): Measuring the influence of enterprises' investment decisions on industrial parks, the author's research results show that, the coefficient of variable $\mathrm{B}=1.544$ shows the positive relationship between the suitability of local institutions and investment decisions, this finding also supports the research of Knack and Keefer (1995), Barro and Sala-i-Martin (1998), which are local institution affirmed to have a positive influence on investment decisions. 
+ Labor (FAC2): Labor is both a factor to attract and effective use of capital attraction. Because when the labor level meets the requirements, high management capacity, it will create high productivity. Also, investors will reduce training costs and reduce training time, so the progress and efficiency of the projects will meet the set goals. The author's research results show that the coefficient $\mathrm{B}=1.214$, these result supports the views of previous studies when labor has a positive relationship with the investment decision.

+ Local advantages (FAC3): Reflecting the level of influence of local advantages on investors' investment decisions. The more local, the higher the comparative advantage and the more investors choose. The author's research results show that the coefficient of variable $\mathrm{B}=0.691$ shows the positive relationship between local advantages and investment decisions, the findings also support the views of other authors (e.g. Durning, 1997; Mai Van Nam \& Nguyen Thanh Vu, 2010; UNIDO, 2015).

+ Infrastructure (FAC4): Reflecting the degree of influence of local infrastructure on investors' investment decisions. Infrastructure is the basis for attracting capital and it is also a factor to promote investment activities that happen quickly and have a decisive influence on production and business efficiency. This is the top concern of investors before making a decision. The author's findings show that the coefficient $\mathrm{B}=0.46$, meaning that the current infrastructure factors and investment decisions of investors are positive together. This result supports the view of author Durning (1997), the theory of local marketing by Kotler et al. (2002) as well as the experiments of Nguyen Dinh Tho (2009), Le Hoang Ba Huyen (2015) when suppose that, poor quality infrastructure system will negatively affect investors' investment decisions.

\section{Table 8}

Variables in the Equation

\begin{tabular}{llllcccc}
\hline & & B & S.E. & Wald & Df & Sig. & Exp(B) \\
\hline Step 1 ${ }^{\mathrm{a}}$ & GT & -.123 & .407 & .091 & 1 & .763 & .885 \\
& HV & -.435 & .176 & 6.069 & 1 & .014 & .647 \\
& KM & .008 & .054 & .022 & 1 & .882 & 1.008 \\
& QM & -.177 & .275 & .414 & 1 & .520 & .838 \\
& TG & -.311 & .080 & 15.063 & 1 & .000 & .733 \\
& FAC1 & 1.544 & .246 & 39.278 & 1 & .000 & 4.683 \\
& FAC2 & 1.214 & .230 & 27.863 & 1 & .000 & 3.368 \\
& FAC3 & .691 & .172 & 16.165 & 1 & .000 & 1.996 \\
& FAC4 & .460 & .183 & 6.302 & 1 & .012 & 1.585 \\
& Constant & .772 & 1.224 & .397 & 1 & .528 \\
\hline
\end{tabular}

\section{Conclusion}

Source: Analysis results from the author's research data

The findings show that to be able to attract investment capital of enterprises in industrial parks, industrial parks in particular and countries have to ensure the following:

Firstly, to ensure human resources for the development of industrial parks since human resource is a decisive factor in the operation of any enterprise, the enterprise cannot perform well if its human resources do not meet the quality and quantity requirements.

Secondly, completing preferential policies and supporting investment for enterprises when investing in industrial parks, this is a factor that creates a competitive advantage for the industrial parks themselves in the problem of attracting investment capital compared to industrial parks of other countries.

Thirdly, improving the capacity of supporting industry to promote support for enterprises in the industrial park when putting into operation

Fourthly, strengthening investment promotion activities-solving the problem of supporting other services for enterprises, these activities will help promote better industrial parks to the enterprises.

Fifthly, synchronously developing infrastructure inside and outside the fence of industrial parks, creating favorable conditions for enterprises

\section{References}

Aggarwal, A. (2007). Impact of special economic zones on employment, poverty and human development (No. 194). Working Paper. 
Alam, K. F., \& Stafford, L. W. T. (1985). Tax incentives and investment policy: A survey report on the United Kingdom manufacturing industry. Managerial and Decision Economics, 6(1), 27-32.

Akifumi, K. (2005). Theory of a Flowchart Approach to Industrial Cluster Policy (No. 36). Institute of Developing Economies, Japan External Trade Organization (JETRO).

Barro, R., \& Sala-i-Martin, X. (1997). Technology diffusion, convergence and growth. Journal of Economic Growth, 2(1), 125.

Lin, C. L., \& Tzeng, G. H. (2009). A value-created system of science (technology) park by using DEMATEL. Expert systems with applications, 36(6), 9683-9697.

Dunning, J. H. (1977). Trade, location of economic activity and the MNE: A search for an eclectic approach. In The international allocation of economic activity (pp. 395-418). Palgrave Macmillan, London.

Knack, S., \& Keefer, P. (1995). Institutions and economic performance: cross-country tests using alternative institutional measures. Economics \& Politics, 7(3), 207-227.

Leung, P. K. (2002). Marketing Asian places: Attracting investment, industry, and tourism to cities, states and nations.

Kotler, P., \& Gertner, D. (2002). Country as brand, product, and beyond: A place marketing and brand management perspective. Journal of brand management, 9(4), 249-261.

Hair, J.F., Balck, W. C., Babin, B. J., \& Anderson, R.E. (2010). Multivariate data analysis. 7th edition. Boston: Pearson.

Gilmore, A., O'Donnell, A., Carson, D., \& Cummins, D. (2003). Factors influencing foreign direct investment and international joint ventures. International Marketing Review, 20(2), 195-215.

Le Hoang Ba Huyen. (2015). factors affecting Foreign Direct Investment in Thanh Hoa province, VNU Journal of Science: Economics and Business, 31(2), 26-37.

Mai Văn Nam \& Nguyễn Thanh Vũ. (2010). Attracting investment into industrial zone and its labor employment in Tien Giang province. Journal science of Can Tho University, 13, $126-136$.

Nelson, R. R. (2005). Technology, Institutions, and Economic Growth. Cambridge, Massachusetts: Harvard University Press.

Nguyen Dinh Tho. (2009). Place Development: Attributes and Business Customer Satisfaction in Tien Giang Province, Vietnam. Journal Macromaketing, 29(4), 384 -391.

Porter, M. E. (2000). Locations, clusters, and company strategy, in G.L. Clark, M.P. Feldman and M.S. Gertler (Eds.). The Oxford Handbook of Economic Geography, (Oxford University Press, Oxford), 253-274.

Porter, M.E. (1990). The Comparative Advantage of Nations (Free Press, New York).

Robbins, S.P. \& Coultar, M. (1996). Management. $5^{\text {th }}$ ed., Published by Prentice Hall International.

Pavabutr, P. (2002). Investor behavior and asset prices, Sangvien Conference Pennings, Assessing the construct validity of risk attitude. Management Science, 46(10), 1337-1348.

Shatz, H. J., \& Venables, A. J. (2000). The geography of international investment, Policy Research Working Paper 2338, The World Bank.

Sandberg, W. R., \& Hofer, C. W. (1987). Improving new venture performance: The role of strategy, industry structure, and the entrepreneur. Journal of Business Venturing, 2(1), 5-28.

UNIDO. (2015). Economics zones in ASEAN, UNIDO country office in Viet Nam.

Yeung, Y. M., Lee, J., \& Kee, G. (2009). China's special economic zones at 30. Eurasian Geography and Economics, 50(2), 222-240.

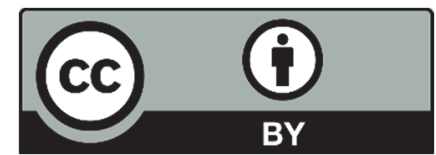

(C) 2020 by the authors; licensee Growing Science, Canada. This is an open access article distributed under the terms and conditions of the Creative Commons Attribution (CC-BY) license (http://creativecommons.org/licenses/by/4.0/). 